\title{
INTERFACES DA ACCOUNTABILITY NA ADMINISTRAÇÃO PÚBLICA BRASILEIRA: ANÁLISE DE UMA EXPERIÊNCIA DA AUDITORIA GERAL DO ESTADO DO RIO DE JANEIRO
}

\author{
Leonardo da Silva Morais * \\ leonsysad@yahoo.com.br
}

\section{Maria Gracinda Carvalho Teixeira* \\ gracinda@uol.com.br}

* Universidade Federal Rural do Rio de Janeiro - Seropédica, RJ / Brasil

http://dx.doi.org/10.1590/1413-2311.014162016.62768

Recebido em 05/03/2016

Aprovado em 24/05/2016

Disponibilizado em 06/06/2016

Avaliado pelo sistema "double blind review"

Revista Eletrônica de Administração

Editora-chefe: Aurora Zen

ISSN 1413-2311 (versão "on line")

Editada pela Escola de Administração da Universidade Federal do Rio Grande do Sul.

Periodicidade: Quadrimestral

Sistema requerido: Adobe Acrobat Reader

\section{RESUMO}

O objetivo da pesquisa foi explorar o sentido do termo accountability e suas interfaces na administração pública brasileira, apontando os avanços e entraves da accountability no Brasil a partir da análise da experiência da Auditoria Geral do Estado do Rio de Janeiro (AGE/RJ) na sua atuação na Copa das Confederações de 2013. A pesquisa procurou investigar de que forma a AGE/RJ promoveu, na experiência em foco, condições para desenvolver accountability no controle interno, como apoio ao controle externo e social no tocante aos recursos públicos gerando transparência. A coleta dos dados decorre de diferentes recursos de investigação, sendo utilizadas fontes bibliográficas, documentais e orais. O estudo contribui com evidências junto ao Poder Executivo na esfera estatal brasileira na questão da efetividade da accountability no que concerne ao sistema de controles na aplicação de recursos públicos e na geração de transparência.

Palavras-Chave: Accountability; Administração Pública Brasileira; Auditoria Geral do Estado do Rio de Janeiro (AGE/RJ); Controle; Responsividade; Transparência.

ACCOUNTABILITY INTERFACES IN THE BRAZILIAN PUBLIC ADMINISTRATION: ANALYSIS OF AN EXPERIENCE OF THE GENERAL AUDIT OF THE STATE OF RIO DE JANEIRO

\footnotetext{
ABSTRACT

The objective of the research was to explore the meaning of the term accountability and its interfaces in the Brazilian public administration, pointing out the advances and obstacles of
} 


\title{
INTERFACES DA ACCOUNTABILITY NA ADMINISTRAÇÃO PÚBLICA BRASILEIRA: ANÁLISE DE UMA EXPERIÊNCIA DA AUDITORIA GERAL DO ESTADO DO RIO DE JANEIRO
}

accountability in Brazil from the analysis of an experiment of the General Audit of the State of Rio de Janeiro (AGE/RJ) and his performance in the Confederations Cup in 2013. The research sought to investigate how the AGE/RJ promoted, in the experience in focus, accountability in internal control, as support for the external and social control as regards public funds generating transparency. The data collection takes place through different research methods, being used bibliographic, documentary and field work sources. The study contributes with evidence by the Executive Power in the Brazilian state sphere on the issue of accountability effectivity with regard to the control system in the application of public resources and to generate transparency.

Keywords: Accountability; Brazilian Public Administration; Control; Responsiveness; Transparency.

\section{INTERFACES DEL ACCOUNTABILITY EN LA ADMINISTRACION PUBLICA BRASILEÑA: ANALISIS DE UNA EXPERIENCIA DE LA AUDITORIA GENERAL DEL ESTADO DE RIO DE JANEIRO}

\begin{abstract}
RESUMEN
El objetivo de la investigación fue explorar el alcance del término accountability y sus interfaces en la administración pública brasileña, señalando los avances y obstáculos del accountability en Brasil a partir del análisis de la experiencia de la Auditoría General del Estado de Río de Janeiro (AGE/RJ) en su actuación en la Copa Confederaciones 2013. La pesquisa tuvo como objetivo investigar la forma en que la AGE/RJ promovió, a través de su experiencia, las condiciones de desarrollar este accountability en el control interno, para apoyar el control externo y social, con respecto a los fondos públicos generando transparencia. La recolección de datos se debe a diferentes recursos de investigación, utilizándose referencias bibliográficas, documentales y fuentes orales. El estudio proporciona evidencias para el Poder Ejecutivo, en el ámbito estatal brasileño, sobre la cuestión de la eficacia del accountability en relación al sistema de controles en la aplicación de los recursos públicos y la generación de transparencia.
\end{abstract}

Palabras clave: Accountability; Administración Pública Brasileña; Control; Grado de Respuesta; Transparencia.

\section{INTRODUÇÃO}

Em outubro de 1988, a Constituição da República Federativa do Brasil, promulgada por meio da Assembleia Nacional Constituinte, reestabelece no país um Estado democrático e de direito. A Carta Magna inaugura um novo período da história brasileira após os regimes ditatoriais no país, que por mais de duas décadas (1964 a 1985) imprimiram autoritarismo, cerceamento aos direitos civis coletivos e individuais com repressão aos opositores, censura à imprensa e liberdade de expressão de toda ordem, perseguições políticas e fortes restrições de atuação das instituições brasileiras.

REAd | Porto Alegre - Edição 83 - N 1 - Janeiro/Abril 2016 - p. 77-105 


\section{Leonardo da Silva Morais \& Maria Gracinda Carvalho Teixeira}

Após a Constituição de 1988 e com o processo de redemocratização que esta alavancou, o país avançou, principalmente no tocante aos direitos civis, às legislações federais específicas para diferentes públicos, e, entre outros avanços políticos, o fortalecimento das suas instituições.

Ressaltam Medeiros, Crantschaninov e Silva (2013, p. 2) que essa nova conjuntura política abre espaço e fortalece a ideia de accountability no Brasil principalmente a partir da discussão da democracia, como princípio fundamental do seu sistema político, legitimado pela Carta Magna. Desde então, explicam os autores que o termo accountability "circunda a literatura em companhia de expressões como controle social, participação e a própria democratização do Estado brasileiro".

Para Campos (1990), à medida que a democracia vai amadurecendo, o cidadão, individualmente, passa do papel de consumidor de serviços públicos e objeto de decisões públicas a um papel ativo de sujeito. Enfatiza a autora que a accountability governamental tende a acompanhar o avanço dos valores democráticos de uma nação, tais como igualdade, dignidade humana, participação, e, entre outros, a representatividade.

O que na teoria já não é simples, na prática torna-se ainda mais complexo. E justamente por ter adquirido vários significados, ao longo da sua trajetória histórica, accountability acabou se tornando um termo multifacetado, portanto de múltiplas dimensões, carregado de significados e aplicabilidades. Nesse percurso, é possível identificar elementos constitutivos da accountability formados de acordo com os contextos histórico-institucionais, políticos e sociais particulares nos quais a accountability se desenvolve.

O caráter multifacetado do termo accountability e o amplo elenco de leis que, de uma forma ou de outra, estão conectados com accountability, dificultam a escolha de uma única perspectiva teórico-conceitual que venha contribuir para que se compreenda a experiência de uma organização brasileira como a Auditoria Geral do Estado do Rio de Janeiro (AGE/RJ), órgão central de controle interno e atuante no âmbito subnacional de governo no que concerne a accountability. Entretanto ao logo da discussão teórica, haverá aquelas que melhor fundamentarão a definição das categorias analíticas do estudo.

A AGE/RJ está vinculada hierarquicamente à Secretaria de Fazenda (SEFAZ/RJ, 2014) na estrutura organizacional do Governo do Estado e uma das suas funções é fiscalizar a atividade dos órgãos da administração direta e indireta do Poder Executivo do Estado responsável pela realização da receita, da despesa e pela gestão do dinheiro público. 


\section{INTERFACES DA ACCOUNTABILITY NA ADMINISTRAÇÃO PÚBLICA BRASILEIRA: ANÁLISE DE UMA EXPERIÊNCIA DA AUDITORIA GERAL DO ESTADO DO RIO DE JANEIRO}

Estudar a accountability no âmbito da AGE/RJ é, portanto um grande desafio visto a abrangência de atuação da instituição e sua conexão com outros órgãos nos vários âmbitos governamentais e a variedade de abordagens e de sentidos do termo accountability.

Tem sido notória a mobilização popular recente por assuntos de interesse coletivo. No bojo das recentes manifestações da sociedade civil, tomaram vulto os protestos sobre os megaeventos esportivos no Brasil, nos estados envolvidos com os eventos, destacando-se aqui o estado do Rio de Janeiro. Destacam-se entre as bandeiras de luta das manifestações, as relacionadas aos custos envolvidos com megaeventos esportivos, com as instalações esportivas, a falta de transparência com o destino dos recursos e dos espaços públicos utilizados nesses megaeventos, a falta de consulta à população nas tomadas de decisões sobre os megaeventos, entre outras.

Diante da situação problemática acima apresentada, formulou-se a seguinte questão de pesquisa: de que forma a AGE/RJ promove condições para desenvolver accountability no controle interno, como apoio ao controle externo e social no tocante aos recursos públicos gerando transparência? A partir dessa indagação, o estudo se propõe a explorar o sentido do termo accountability e suas interfaces na administração pública brasileira, apontando os avanços e entraves da accountability no Brasil a partir da análise da experiência da uma organização pública, a Auditoria Geral do Estado do Rio de Janeiro e sua atuação na Copa das Confederações de 2013.

Para apresentar a pesquisa realizada, estruturou-se esse artigo em quatro partes. Após a introdução, a primeira parte apresenta a fundamentação teórica do trabalho subdividido em três seções: accountability: origem do conceito e significados, as interfaces da accountability com democracia, transparência e controle e accountability e a questão dos controles na administração pública brasileira. A segunda parte trata da abordagem metodológica do estudo. A terceira registra a análise de dados e os resultados da pesquisa. Por último, apresentam-se as considerações finais do trabalho.

\section{FUNDAMENTAÇÃO TEÓRICA}

\subsection{Accountability: origem do conceito e significados}




\section{Leonardo da Silva Morais \& Maria Gracinda Carvalho Teixeira}

A accountability surge relacionada à noção de controle externo, conceito que conforme começou a ser estruturado por pensadores como Locke no fim do século XVII, e Montesquieu, no século XVIII, mas que já aparecia no fim da Idade Média na Inglaterra, além de França e Espanha, onde já podia ser localizada, naquela época, segundo os estudos de Pessanha, a menção a uma ideia de "Corte de Contas" (Pessanha, 2007).

O controle externo, que pode ser definido como "todo controle exercido por um Poder ou órgão sobre a administração de outros” (LIMA, 2008, p. 8), se origina, por sua vez, dos primeiros mecanismos de limitação do poder do governante. Lembra Pessanha que "para o pensador Locke o soberano é o supremo executor da lei, mas quando a viola perde o direito à obediência" (PESSANHA, 2007, p.140; PESSANHA, 2009).

Explorando as raízes históricas do significado de accountability, vale ressaltar a importância das ideias do pensador Montesquieu (1985) quando ele explica que, proteger a liberdade política consiste, acima de tudo, em construir um equilíbrio. No plano institucional, isso se consegue como explica o referido filósofo, com a criação de um sistema de "freios e contrapesos", o que os americanos nomeariam mais tarde de sistema de "checks and balances", baseado na noção de Montesquieu de que o próprio poder pode ser usado para evitar ou combater o abuso de poder. Tal ideia de controle, originada no período medieval levaria, mais tarde ao desenvolvimento de mecanismos de controle externo presentes nas constituições modernas, no sentido de controle da ação do governante, dando base ao surgimento do Estado moderno. Complementa Pessanha (2007) com base nas ideias de Montesquieu que os "checks and balances" realizados entre os três Poderes: Legislativo, Executivo e Judiciário, os quais limitam a autoridade e abuso de poder com todos se auto vigiando. Tal distribuição de autoridade é à base do constitucionalismo, como enfatiza Pessanha (2009), pois um dos papéis de uma Constituição é justamente distribuir a autoridade entre os Poderes numa sociedade - e, logo, a forma e o nível de controle externo de cada Poder sobre o outro.

O que se percebe, na interpretação de Pessanha (2009) é que, apesar da relevância das leis, já apontada no século XVII com Locke, as tarefas de fiscalização e o controle também chamavam forte atenção também no século XVIII com Montesquieu.

Como foi visto nessa breve retrospectiva histórica, a noção de controle do outro está conectada com o conceito de controle externo, o que, de acordo com Pessanha (2007,114), "motivou todo o constitucionalismo liberal dos séculos XIX e XX" e influenciando a construção de conceitos como prestação de contas, ou transparência, ou accountability. Observa-se também que a gênese do conceito de controle externo parece encontrar explicação 


\section{INTERFACES DA ACCOUNTABILITY NA ADMINISTRAÇÃO PÚBLICA BRASILEIRA: ANÁLISE DE UMA EXPERIÊNCIA DA AUDITORIA GERAL DO ESTADO DO RIO DE JANEIRO}

nas primeiras formas de limitação do poder do governante e que é dessa ideia que se origina a contemporânea accountability.

Contudo, não há um consenso entre os autores sobre o sentido de accountability, pois as distintas abordagens apontam diferentes significados.

Para Baquero (2008), o exercício da cobrança de direitos, por parte do povo aos deveres assumidos pelos seus representantes, é uma forma de caracterizar o processo que vem sendo amplamente compreendido como accountability. Nessa caracterização, como explica o autor, está contido um sentido moral, pela sociedade, de adjudicar a prestação de contas dos seus representantes, o que supostamente traz elementos para que a população possa avaliar a eficiência e a efetividade da gestão pública.

Nesse sentido, o autor Mainwaring (2003) explica que a accountability foi posta como um dos focos de atenção e estudo na América Latina a partir dos anos 1980, no que ele se refere como o período de pós-transição democrática no continente. A partir de então, ensina Mainwaring que a preocupação em relação à accountability no âmbito políticoestatal ultrapassou do campo da accountability, até então mais voltada para o campo eleitoral, e estendeu-se por outras esferas da vida política do continente, emergindo como importante desafio para melhorar a qualidade das democracias da América Latina, que passam a construir mecanismos mais efetivos de accountability. Ressalta ainda o autor que, embora accountability desde então tenha se tornado uma preocupação proeminente na América Latina, só recentemente começa a emergir na literatura acadêmica um debate mais voltado para campos de estudos que não se debrucem apenas sobre o viés que relaciona accountability à questão eleitoral ou de representatividade no sistema político do país. A observação de Mainwaring (2003) encontra apoio na argumentação de Ana Maria Campos (1990), apresentada acima, que relaciona o avanço da democracia de um país com o interesse dos cidadãos pela accountability.

Além da recorrente contribuição de Ana Maria Campos (1990) no tema da accountability, outros estudiosos do assunto, como Sano (2003), Pinho e Sacramento (2009), Sacramento e Pinho (2012), Raupp e Pinho (2014) e também estudos registrados no Centro Latino-Americano de Administração para o Desenvolvimento (CLAD), publicados em 2000, atestam que a falta de um termo em português, e também em espanhol, que designe adequadamente a essência da accountability seria uma indicação de que é ainda incipiente a consolidação do próprio conceito no país e na América Latina em geral. Em registros do CLAD explica-se essa ausência: 


\title{
Leonardo da Silva Morais \& Maria Gracinda Carvalho Teixeira
}

\begin{abstract}
Percebe-se um consenso entre os autores de que a dificuldade para se obter uma tradução imediata e precisa para o termo não reside simplesmente na inexistência do termo na América Latina (...). E, para complementar o raciocínio, não é difícil concluir que se um idioma é incapaz de expressar conceitos (...) com uma única palavra, isso se deve à ideia subjacente a esses conceitos de que esses conceitos não fazem parte daquela cultura vigente (tradução do pesquisador) (CLAD, 2000, p.329).
\end{abstract}

Trazendo essa discussão especificamente para o Brasil, a inexistência do termo accountability em português, com a presença apenas da sua expressão de origem, "prestação de contas", termo que designa somente um lado do processo, o das demonstrações contábil- financeiras, na visão de Sano, talvez seja um indício de que esse sentido restrito revele que uma noção mais ampla de accountability ainda não tenha sido internalizada pelas democracias da América Latina, destacando-se aí o Brasil (SANO, 2003, p. 32-33).

Nesse sentido, Raupp e Pinho (2014), assim como Pinho e Sacramento (2009) confirmam que a questão da prestação de contas explica apenas parte do conceito de accountability, cujo significado é mais abrangente, envolvendo "responsabilidade (objetiva e subjetiva), controle, transparência, obrigação de prestação de contas, justificativas para as ações que foram ou deixaram de ser empreendidas, premiação e/ou castigo" (RAUPP; PINHO, 2014, p. 145).

Há também autores, como Michael Power (1999), que apresentam uma visão distinta de accountability, compreendendo-a como instrumental trazido do mundo das corporações financeiras e disseminado no setor público, com as mudanças estruturais ocorridas na esfera pública. No seu livro The audit society - rituals of verification, Power (1999) ressalta que, quando o mundo das finanças requereu demanda por auditoria e accountability financeira e contábil, isso provocou uma mudança na governança daquele mundo específico; da mesma forma, a transposição da demanda de accountability para outras áreas, como a estatal, rendeu a elas "uma reinvenção de sua governança" (POWER, 1999, p. 41). Para Power, a accountability então passa a introduzir o sentido de limitação do poder do governante, na sua responsabilização política que isso acarreta. Assim, enfatiza o referido autor que accountability, nesse contexto, tem o poder de reinventar, ou melhor, consolidar a governança do Estado. Em suma, Power (1999) acredita que tal demanda começou no mundo econômico-financeiro, pois o crescente interesse por accountability e a importância da prestação de contas veio, em boa parte, conforme defende o autor, pelo aumento da prática de auditoria financeira (auditing) e de fornecimento de selos e certificações de qualidade (os 


\section{INTERFACES DA ACCOUNTABILITY NA ADMINISTRAÇÃO PÚBLICA BRASILEIRA: ANÁLISE DE UMA EXPERIÊNCIA DA AUDITORIA GERAL DO ESTADO DO RIO DE JANEIRO}

ISOs 9000 e afins) no final dos anos 1980, no que Power chama de consolidação de uma "audit society" (POWER, 1999, p. 4).

O referido autor explica que durante os finais dos anos de 1980 e início de 1990, o verbo auditar passou a ser usado na Inglaterra de uma forma crescente em contextos variados: na regulação de auditoria de companhias privadas, na prática de auditoria ambiental, na auditoria de gestão, na auditoria forense, na auditoria de propriedade intelectual, na auditoria médica, na auditoria de ensino, na auditoria de tecnologia entre muitas outras, o que acabou levando a auditoria a um nível de estabilidade e aceitação institucional, influenciando outros países.

A partir desse ambiente "accountable" (“auditável”) criado pelas finanças e pelo setor privado, assim como esclarece Power, a prática de accountability se espalharia por outras esferas, inclusive a estatal, auxiliada pela vinda do que se chamou New Public Management (POWER, 1999, p. 10).

Essa discussão atraiu a atenção dos pesquisadores, autores do presente estudo, uma vez que, além das contribuições dos vários autores que se dedicam a este objeto, alguns dos aspectos dessa reinvenção na área pública, apontados por Power, como, por exemplo, o desenvolvimento de um sistema interno de accountability e a capacidade de aprendizado que essa accountability interna traz para uma organização, podem ampliar a compreensão dos interessados pelo tema, sobre o desenvolvimento de accountability no Brasil, na gestão de auditoria governamental na esfera estatal e suas interações com a sociedade. Nesse sentido o estudo pode contribuir com evidências do Executivo brasileiro na questão da accountability.

Acrescentam Abrucio e Loureiro (2004, p. 75) que "normalmente a literatura sobre accountability trata do controle dos atos dos governantes em relação ao programa de governo, à corrupção ou à preservação de direitos fundamentais dos cidadãos”. Todavia, de certa forma, alinhados à visão de Power (1999), alertam Abrucio e Loureiro para o fato de que o tema recentemente também tem sido tratado no contexto da reforma do Estado e da administração pública, notadamente nas discussões sobre de que maneira transparência e responsabilização podem melhorar a eficiência da ação governamental e da gestão pública. Todavia, como se mencionou no debate inicial do presente trabalho, há tantos outros significados constitutivos da accountability, requerendo que se entendam as interfaces teórico-conceituais que o termo traduz, para uma melhor visão da sua dimensão multifacetada. 


\section{Leonardo da Silva Morais \& Maria Gracinda Carvalho Teixeira}

\subsection{As interfaces da accountability com democracia, transparência e controle}

De acordo com Campos (1990, p. 30), "nas sociedades democráticas mais modernas se aceita como natural e espera-se que os governos - e o serviço público - sejam responsáveis perante os cidadãos" e que "accountability não é apenas uma questão de desenvolvimento organizacional ou de reforma administrativa". Argumenta a autora que a interpretação de accountability como "a simples criação de mecanismos de controle burocrático não se tem mostrado suficiente para tornar efetiva a responsabilidade dos servidores públicos" (CAMPOS, 1990, p. 30-31). Defende ainda que o desenvolvimento da accountability transcende meios formais e requer a emergência de valores culturais para que sejam, portanto incorporados os meios formais dos quais dependem a accountability. Por consequência, fica intrinsicamente ligada à democracia formal e informal de forma participativa, na sua visão.

Nessa mesma direção, e resgatando a discussão inicial deste trabalho, é importante trazer à tona a ênfase dada por Medeiros, Crantschaninov e Silva (2013) ao termo accountability, ressaltando a preocupação dos autores com a relação entre este termo e a democracia. Para os autores, é preciso se discutir sobre a democracia para entender accountability.

Para Bobbio (1986), um regime democrático deve contemplar um conjunto de regras, primárias ou fundamentais, de procedimentos para a formação de decisões coletivas, em que está prevista e facilitada à participação mais ampla possível dos interessados. Nesse sentido, a democracia pode ser entendida como um método para a constituição de governo e para a formação das decisões que abrangem toda a sociedade.

A contínua responsividade do governo às preferências dos seus cidadãos é uma característica chave para que uma democracia torne-se efetiva. Os cidadãos devem ter a oportunidade de formular suas preferências, expressá-las por meio da ação individual e/ou coletiva, bem como considerá-las nas ações governamentais (DAHL; LIMONGI; PACIORNIK, 1997). A democracia, enquanto forma política sobre um dado território, está necessariamente conectada à cidadania, e esta só pode existir dentro da legalidade de um Estado democrático (O’DONNELL, 1998).

Baquero (2008) então sugere que a democracia contemporânea requer uma cidadania ativa que se envolva na arena política via discussões, deliberações, referendos e plebiscitos, ou seja, por meio de mecanismos formais e informais, sem que isso comprometa as

REAd | Porto Alegre - Edição 83 - N 1 - Janeiro/Abril 2016 - p. 77-105 


\section{INTERFACES DA ACCOUNTABILITY NA ADMINISTRAÇÃO PÚBLICA BRASILEIRA: ANÁLISE DE UMA EXPERIÊNCIA DA AUDITORIA GERAL DO ESTADO DO RIO DE JANEIRO}

instituições convencionais de mediação política. Nesse sentido, espera-se que os cidadãos decidam o futuro dos seus países através de seus representantes que por sua vez, devem prestar contas à sociedade de como e onde os recursos públicos são aplicados. Assim, a reflexão que se apresenta vincula democracia a accountability.

Nos trabalhos desenvolvidos por Platt Neto, et al. (2007), os autores se baseiam em Iudícibus, Marion e Pereira, para elucidar a noção e uso de accountability como uma espécie de responsabilidade do gestor profissional de prestar contas. Já Nakagawa (1998, p. 17) caracteriza accountability como "a obrigação de se prestar contas dos resultados obtidos em função das responsabilidades que decorrem de uma delegação de poder”.

Corrobora dessa visão, o Centro Latino-Americano de Administração para o Desenvolvimento (CLAD) (2000), segundo o qual, a realização do valor político da accountability depende de dois fatores: do desenvolvimento da capacidade dos cidadãos de agir na definição de metas coletivas de sua sociedade e da construção de mecanismos institucionais democráticos que garantam o controle público e transparência das ações dos governantes nas várias esferas de governo e dos gestores ao longo dos seus mandatos.

Para Sacramento e Pinho (2012), o enfraquecimento das instituições, a baixa organização politica por parte da sociedade e também a corrupção contribuem para fortalecer o argumento de diversos estudiosos da accountability quanto à fragilidade dos mecanismos de accountability existentes no Brasil. Nesse sentido, uma das principais preocupações dos mencionados autores é o descrédito em relação à accountability uma vez que para estes, a sociedade brasileira estaria construída e preparada para aceitar níveis suportáveis de corrupção por parte dos seus governantes desde que o governo/governante ofereça contrapartida à sociedade, ou melhor, se disponha a atender demandas da sociedade.

Para Mainwaring (2003, p. 7), “accountability ou o ato de ter um agente público que formal e legalmente presta contas a outro ator" possui três principais elementos formadores. $\mathrm{O}$ primeiro, transparência, surge na literatura inglesa com o sentido de answerability, traduzindo "a divulgação de informações, uma postura transparente de transmitir a informação". Outro elemento identificado pelo referido autor é a responsividade que também se origina do inglês responsiveness, significando "a obrigação legal de responder a questionamentos e demandas de informações, com responsabilização pelos próprios atos"; e por último, a capacidade de sanção e coerção, também originado do inglês enforcement, o que denota a capacidade, também legal e institucional, de o agente que exige as informações e contas de outro agente fazer valer essa exigência, tornando-a obrigatória, por meio de sanções e incentivos.

REAd | Porto Alegre - Edição 83 - N 1 - Janeiro/Abril 2016 - p. 77-105 


\section{Leonardo da Silva Morais \& Maria Gracinda Carvalho Teixeira}

O conceito de transparência está intrinsicamente vinculado à qualidade da democracia e ao exercício da accountability assim como sugere Heald (2007). Para este autor, transparência no governo nacional e subnacional é uma forma de abertura nas relações entre governos e entre os estados e organismos internacionais. Para Heald, transparência pode ser entendida como:

Uma construção física que exerce poder simbólico, para além do seu uso metafórico, em práticas discursivas, sobre as maneiras com que os assuntos de negócios privados e públicos devem ser realizados. É essencial alinhar a relação entre transparência, abertura e vigilância governamental. [...] Os governos devem ser os mais abertos possíveis sobre as decisões e ações tomadas (HEALD, 2007, p. 25. Tradução própria).

Para a organização não governamental Transparência Internacional "transparência é a característica de governos, empresas, organizações e indivíduos em serem abertos em relação a informações sobre planos, regras, processos e ações" (TRANSPARENCY INTERNATIONAL, 2009, p. 44, tradução própria). Isso mostra que o conceito de transparência transcende o seu entendimento no âmbito dos governos.

Michener e Bersch (2011, p.1-2) defendem que um sistema de governo transparente está condicionado à "visibilidade" e "inferabilidade". A visibilidade eles conceituam como "o grau no qual as informações estão completas e podem ser facilmente localizadas". Essa condição, para os autores, apesar de necessária, é insuficiente para gerar transparência. Já a condição de inferabilidade é aquela em que "a informação pode ser usada para prover inferências", ou seja, é necessário que a informação disponibilizada possibilite inferências corretas. Os autores sugerem que se a informação desejada não estiver plena e facilmente disponível, o sistema deverá indicar onde e de que maneira o cidadão poderá acessar a informação requerida ou mesmo, o detentor da informação solicitada deverá simplesmente entregar a informação ao solicitante. A transparência, assim como discutida por esses autores, portanto, não seria um fim em si mesmo, mas uma maneira para que se conheça melhor o que ocorre no interior das organizações. Ou seja: a transparência será tão mais útil quanto maior for a sua contribuição a um sistema de prestação de contas efetivo, que resulte em inferências corretas.

Corroborando os argumentos de Michener e Bersch (2011), Platt Neto et al. (2007, p.76) esclarecem que "no Brasil, a transparência é considerada um princípio da gestão fiscal responsável que deriva do princípio constitucional da publicidade". No entanto, alertam os autores que embora transparência esteja regida por leis, a exemplo da Lei de Responsabilidade Fiscal (LRF) e da Lei ${ }^{\circ}$ 9.755/98, é um conceito mais amplo do 


\section{INTERFACES DA ACCOUNTABILITY NA ADMINISTRAÇÃO PÚBLICA BRASILEIRA: ANÁLISE DE UMA EXPERIÊNCIA DA AUDITORIA GERAL DO ESTADO DO RIO DE JANEIRO}

que a publicidade, porque, para os autores, "uma informação pode ser pública, mas não ser relevante, confiável, tempestiva e compreensível” (PLATT NETO, et al., 2007. p. 76-77).

Vale lembrar o que nos ensina Pessanha (2009), que as instituições de controle assumiram historicamente duas formas distintas: a auditoria geral e o tribunal de contas. Entretanto, complementa o autor que as atribuições dessas instituiçõos de controle, bem como sua posição na estrutura governamental e o próprio desenho institucional foram se modificando ao longo do tempo e de acordo com os contextos, o que explica as complexas formas de expressão de controle hoje inerentes à accountability nessas instituições, como será visto a seguir.

\subsection{Accountability e a questão dos controles na Administração Pública}

\section{brasileira}

A accountability contemporânea supõe a answerability, o que antes se conhecia como o fornecimento de informações, o que traz a noção atual de transparência. Entretanto os estudiosos de accountability chamam atenção para o fato de que o fornecimento de informações, ou melhor, o acesso à informação apenas, não garante a responsividade que requer os processos de controle internos ou públicos, ou seja, o controle não somente daquilo que foi realizado, mas com qual finalidade e de que maneira.

Considerando ser esse o marco inicial do controle social no país, Serra e Carneiro (2011), ao examinarem os laços de conexão entre o controle social, o controle interno e o externo na administração pública brasileira, ressaltam que a CF/1988 consigna quatro canais básicos por onde o exercício do controle da administração pública pode ocorrer: i) o primeiro, pela via judicial, através da qual o Judiciário é chamado a examinar a legalidade da ação administrativa questionada; (ii) o segundo, por meio do controle interno, realizado no seio da própria administração; (iii) o terceiro pela via do controle externo, a cargo do Poder Legislativo e Tribunais de Contas; (iv) o último o quarto ocorre através do controle social, realizado pelo cidadão, grupo de cidadãos ou sociedade (BRASIL, 1988).

Enfatizam Serra e Carneiro (2011) que a legalidade e exigência dos controles emergem a partir da Constituição Federal que determina o âmbito de atuação de cada um dos controles de forma que haja uma relação contínua sem sobrepor as esferas competentes.

No caso do controle interno, este passou a ser obrigatório dentro de cada órgão ou entidade administrativa, sendo que, em sua ausência, seu responsável legal responde por 


\section{Leonardo da Silva Morais \& Maria Gracinda Carvalho Teixeira}

eventuais falhas. Restou também incumbido de, dentre outras funções consignadas no art. 74 da $\mathrm{CF} / 88$, apoiar o controle externo no exercício de sua missão institucional. Ademais, "os responsáveis pelo controle interno ao tomarem conhecimento de qualquer irregularidade ou ilegalidade, dela darão ciência ao Tribunal de Contas (...) sob pena de responsabilidade solidária" (Art. 74, $\S 1^{\circ}, \mathrm{CF} / 88$ ). Assim, nos parece que o controle interno deve contribuir para o desempenho do controle externo.

Toda essa dinâmica forma o chamado Sistema de Controles na Administração Pública (SCAP), cuja matriz decorre do traçado constitucional composto pelo controle judicial, o controle interno, o controle externo e o controle social.

É necessário se ter clareza sobre a questão do controle e a interface que esse elemento estabelece com accountability uma vez que interessa à pesquisa aprofundar mais sobre essa particular interface. Isso porque a AGE/RJ, como órgão central do controle interno estadual é o local onde é possível entender de que forma é realizado esse controle e como é desenvolvido a accountability relacionada a esse controle.

Ao discutir sobre as dimensões da accountability anteriormente nesse trabalho vimos que historicamente a noção de controle externo originou o conceito contemporâneo de accountability que ao longo do tempo agregou também outras faces como o controle interno, que seriam formas de acompanhamento e controle dentro de uma organização para serem aplicadas no monitoramento das ações da própria organização, o que é o caso da atuação da AGE/RJ.

Também há a categoria chamada controle social, que pode ser explicada como um tipo de controle e uma fiscalização de agentes públicos por parte de grupos da sociedade civil (numa relação vertical de poder em relação ao poder público); as eleições seriam a forma mais institucionalizada de controle social, mas há também outras formas como demandas por informação, denúncias e ações de acompanhamento feitas por entidades da sociedade ou pela imprensa, por exemplo.

$\mathrm{Na}$ literatura, os controles apresentam possibilidades e limitações, o que alguns colocam como prós e contras quanto à sua execução e não há consenso entre os diferentes olhares dos autores.

Para Serra e Carneiro (2011, p. 14), "o controle social, junto ao controle interno e externo, na esfera estadual de governo, está mais bem resolvido na legislação e estrutura formal do que na prática, mas é um processo em construção que tem registrado avanços, ainda que em ritmo lento". Os autores julgam que os lentos avanços podem ser decorrentes de vontade política e não por falta de meios para viabilizar o controle social, como por exemplo,

REAd | Porto Alegre - Edição 83 - N 1 - Janeiro/Abril 2016 - p. 77-105 


\section{INTERFACES DA ACCOUNTABILITY NA ADMINISTRAÇÃO PÚBLICA BRASILEIRA: ANÁLISE DE UMA EXPERIÊNCIA DA AUDITORIA GERAL DO ESTADO DO RIO DE JANEIRO}

o apoio técnico e tecnológico e que a convergência entre os controles internos, externo e social possibilita o esclarecimento de informações à população de modo geral.

Todavia, na argumentação de Platt Neto, et al. (2007) há outras questões a serem observadas que dificultam o controle social, por exemplo, a situação de que muitos dados disponibilizados à população apresentam linguagem técnica especializada, porquanto, de difícil compreensão para pessoas leigas:

Para uma compreensão adequada, as contas públicas deveriam estar expressas em linguagem acessível aos usuários, na condição de receptores da comunicação necessária. Todavia, quando se transporta esse pressuposto para a divulgação de informações de caráter público e orientadas ao controle social, depara-se com uma barreira maior do que no contexto empresarial. Essa barreira está vinculada ao perfil e aos interesses dos usuários, principalmente quando predominam os cidadãos comuns (PLATT NETO, et al., 2007, p. 86).

O avanço do controle social requer um diálogo mais amigável e de fácil entendimento com a população, o que facilitaria a cobrança da sociedade perante os gestores.

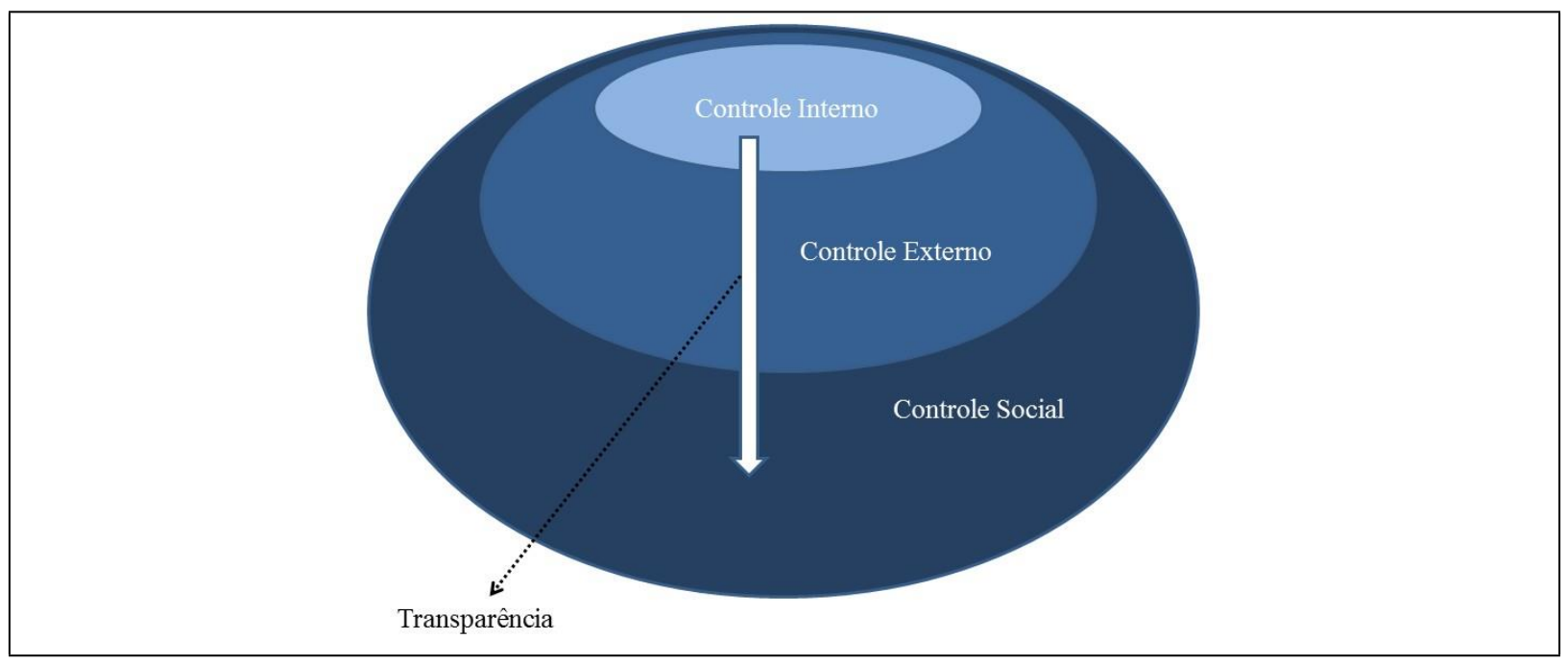

Figura 1 - Sincronismo entre os Controles

Fonte: Elaboração própria a partir Platt Neto, et al., 2007 e de Serra e Carneiro, 2011.

Conforme demonstra a figura 1, os controles são sincrônicos e podem ocorrer simultaneamente. Para o exercício dos controles é necessário que haja publicização das informações com clareza, de tal forma que seja compreensível pelos diferentes públicos. A transparência dos dados permite que todos os estágios de controles possam ser executados da melhor forma possível. Por meio da transparência é possível que em qualquer estágio de controle permita-se entender quem e como foram geradas as informações.

As informações produzidas pelo controle interno, quando elaboradas e disponibilizadas de forma clara, permitem que o controle externo também ocorra. Por sua vez, o controle externo, após tratar e disponibilizar os dados, igualmente de forma clara, 


\section{Leonardo da Silva Morais \& Maria Gracinda Carvalho Teixeira}

permite que se processe o controle social.

\section{ABORDAGEM METODOLÓGICA}

Face ao objeto em estudo, a pesquisa é de natureza qualitativa do tipo descritivo e analítico. A coleta dos dados decorreu de diferentes recursos de investigação, sendo eles de fontes bibliográficas, documentais e orais.

As fontes documentais utilizadas no estudo foram legislações inerentes ao tema, sendo elas: (CF/1988); Lei Complementar Federal 101/2000, que estabelece normas de finanças públicas voltadas para a Responsabilidade na Gestão Fiscal e dá outras providências; Lei Complementar Federal 12.527/2011, que trata do Acesso à Informação e o Decreto Estadual 43.463/2012. Relatórios da AGE/RJ também foram consultados na pesquisa documental destacando-se: o Relatório de Contas de Gestão elaborado pela AGE/RJ (2014) e o Relatório de Atividades da AGE/RJ (2012 e 2013).

Já as fontes orais foram provenientes de entrevistas, o que proporcionou aos pesquisadores a compreensão do mundo dos respondentes, a identificação de crenças, atitudes, valores e motivações (BAUER, 2005), relacionadas ao objeto em investigação.

Os critérios de seleção para a participação da entrevista foram baseados na escolha de servidores públicos com grande experiência e tempo acumulado em cargos de gestão considerados estratégicos na Auditoria Geral do Estado do Rio de Janeiro, e que possuem o poder de influenciar ações de accountability na organização pública em questão.

Assim ficou definido pela ordem das entrevistas no tempo: entrevistado 01: o Superintendente das Coordenadorias Setoriais de Auditoria da Administração Direta; entrevistado 02: o Superintendente de Planejamento e Normas de Auditoria; entrevistado 03: o Auditor Geral do Estado; entrevistado 04: o Superintendente das Coordenadorias Setoriais de Auditoria da Administração Indireta; e entrevistado 05: o Superintendente de Auditoria Operacional e de Ações Estratégicas.

As questões norteadoras das entrevistas foram formuladas com base nas categorias de análise, por temática, tal como se observa no quadro 1. 


\section{INTERFACES DA ACCOUNTABILITY NA ADMINISTRAÇÃO PÚBLICA BRASILEIRA: ANÁLISE DE UMA EXPERIÊNCIA DA AUDITORIA GERAL DO ESTADO DO RIO DE JANEIRO}

Quadro 1 - Categorias: Principais Definições e Atributos

\begin{tabular}{|c|c|c|}
\hline CATEGORIAS & DEFINIÇÕES & ATRIBUTOS \\
\hline Accountability & $\begin{array}{l}\text { “Accountability não é apenas uma questão } \\
\text { de desenvolvimento organizacional ou de } \\
\text { reforma administrativa (...). É determinada } \\
\text { pela qualidade das relações entre governo e } \\
\text { cidadão" (CAMPOS, 1990, p. 35). } \\
\text { Caracteriza-se como "a obrigação de se } \\
\text { prestar contas dos resultados obtidos em } \\
\text { função das responsabilidades que decorrem } \\
\text { de uma delegação de poder” } \\
\text { (NAKAGAWA, 1998, p. 17) }\end{array}$ & $\begin{array}{l}\text { Compreender a } \\
\text { percepção de } \\
\text { accountability e sua } \\
\text { atuação na AGE/RJ }\end{array}$ \\
\hline Controle & $\begin{array}{l}\text { “Ao situar junto aos controles interno e } \\
\text { externo da AP ferramentas para ação do } \\
\text { controle social, o novo arranjo institucional } \\
\text { do SCAP instrumentaliza a formação de } \\
\text { parceria entre a sociedade e a } \\
\text { Administração e a sociedade e o Estado, } \\
\text { propiciando a participação popular na } \\
\text { condução da conformação da ação pública, } \\
\text { ao mesmo tempo em que reforça os } \\
\text { controles interno e externo, que passam a } \\
\text { utilizar o controle social como ferramenta } \\
\text { para o aprimoramento de suas atividades } \\
\text { (...)" (SERRA e CARNEIRO, 2011, p. 4). }\end{array}$ & $\begin{array}{l}\text { Identificar de que modo } \\
\text { ocorre a função do controle } \\
\text { pela AGE/RJ. }\end{array}$ \\
\hline Responsividade & $\begin{array}{l}\text { Originada do termo inglês responsiveness, } \\
\text { significa "a obrigação legal de responder a } \\
\text { questionamentos e demandas de } \\
\text { informações, com responsabilização pelos } \\
\text { próprios atos". Responsividade vai além da } \\
\text { noção de responsabilidade } \\
\text { (MAINWARING, 2003, p. 7). }\end{array}$ & $\begin{array}{l}\text { Detectar como ocorre a } \\
\text { responsividade da AGE/RJ e } \\
\text { da sociedade na cobrança por } \\
\text { melhorias no controle } \\
\text { institucional e social. }\end{array}$ \\
\hline Transparência & $\begin{array}{l}\text { Originada do termo inglês answerability } \\
\text { traduz- se como "a divulgação de } \\
\text { informações, uma postura transparente de } \\
\text { transmitir a informação" (MAINW ARING, } \\
\text { 2003, p. 7). } \\
\text { Embora transparência esteja regida por leis, } \\
\text { é um conceito mais amplo do que a } \\
\text { publicidade, porque, "uma informação pode } \\
\text { ser pública, mas não ser relevante, } \\
\text { confiável, tempestiva e compreensível" } \\
\text { (PLATT NETO, et al., 2007. p.76-77). }\end{array}$ & $\begin{array}{c}\text { Identificar de que forma é } \\
\text { gerada a transparência pela } \\
\text { AGE/RJ. }\end{array}$ \\
\hline
\end{tabular}

Fonte: Elaboração própria.

Para o tratamento dos dados empíricos optou-se pela análise interpretativa nos moldes de Denzin e Lincoln (2006), o que requereu dos pesquisadores uma profunda preocupação com a compreensão daquilo que estava sendo verbalizado pelos sujeitos. Isso exigiu esforços específicos dos pesquisadores, no tocante a compreensão dos relatos e o significado do que foi falado para os próprios pesquisadores.

Os pesquisadores estiveram atentos aos fatores limitantes do método no tocante a representatividade e à subjetividade de documentos da organização, por estes possuírem "o 


\section{Leonardo da Silva Morais \& Maria Gracinda Carvalho Teixeira}

olhar" das organizações. Essas limitações foram superadas com a utilização de um número significativo de documentos de modo a validar as informações das fontes. E sobre o conteúdo das entrevistas, é possível que tenha ocorrido omissão de dados ou discursos estratégicos nas respostas às questões dirigidas aos sujeitos uma vez que foram entrevistadas pessoas que ocupam cargos estratégicos dentro da organização. Como forma de atenuar estes riscos, foi realizada a triangulação na análise dos dados bibliográficos, documentais e empíricos, buscando-se imprimir maior confiabilidade nos resultados da pesquisa.

\section{ANALISE DOS RESULTADOS DA PESQUISA}

\subsection{Breve caracterização da Auditoria Geral do Estado do Rio de Janeiro}

Com as mudanças surgidas da fusão do antigo Estado do Rio e o Estado da Guanabara gerando a criação do atual Estado do Rio de Janeiro, uma série de medidas legais foi tomada para o ordenamento e funcionamento da nova situação, dentre elas a criação em 1974, da Auditoria Geral do Estado - AGE/RJ (FERREIRA E GRYNZPAN, 1994). Desde então, o órgão sempre esteve vinculado hierarquicamente à Secretaria de Fazenda do Estado do Rio de Janeiro, desta dependendo físico e financeiramente.

De acordo com a Constituição Estadual do Estado do Rio de Janeiro de 1989, no artigo 122, a fiscalização contábil, financeira, orçamentária, operacional e patrimonial do Estado e das entidades da administração direta e indireta, quanto à legalidade, legitimidade, economicidade, aplicação das subvenções e renúncia de receitas, será exercida pela Assembleia Legislativa, mediante controle externo e pelo sistema de controle interno de cada Poder (RIO DE JANEIRO, 1989). No âmbito do Poder Executivo do Estado do Rio de Janeiro o controle interno é exercido pela Auditoria Geral do Estado (AGE/RJ). O órgão relaciona-se direta e indiretamente com entes de controle interno de outros estados, com as secretarias do governo estadual, com municípios do Estado do Rio de Janeiro e também com órgãos do controle externo, realizando inúmeras atividades (AGE/RJ, 2014), conforme dispostas no quadro 2 .

REAd | Porto Alegre - Edição 83 - № 1 - Janeiro/Abril 2016 - p. 77-105 
INTERFACES DA ACCOUNTABILITY NA ADMINISTRAÇÃO PÚBLICA BRASILEIRA: ANÁLISE DE UMA EXPERIÊNCIA DA AUDITORIA GERAL DO ESTADO DO RIO DE JANEIRO

Quadro 2 - Atividades Realizadas pela AGE/RJ

\begin{tabular}{|c|c|c|c|c|c|}
\hline MODALIDADES DE PROCESSOS & 2009 & 2010 & 2011 & 2012 & 2013 \\
\hline Adiantamento & 0 & 0 & 1 & 0 & 0 \\
\hline Assembleia Geral Ordinária/Assembleia Geral Extraordinária & 4 & 5 & 3 & 0 & 0 \\
\hline Auditoria Especial & 1 & 0 & 1 & 0 & 0 \\
\hline Consultas & 16 & 7 & 1 & 9 & 7 \\
\hline Contratação de Auditoria & 0 & 1 & 0 & 0 & 0 \\
\hline Contrato & 23 & 32 & 61 & 25 & 67 \\
\hline Convênio & 66 & 167 & 102 & 57 & 177 \\
\hline Crédito Suplementar & 23 & 52 & 62 & 90 & 99 \\
\hline Diligência TCE/RJ & 23 & 85 & 39 & 41 & 120 \\
\hline Prestação Contas Almoxarifado & 104 & 97 & 75 & 109 & 68 \\
\hline Prestação Contas Bens Patrimoniais & 1615 & 2124 & 1711 & 1405 & 1181 \\
\hline Prestação Contas Ordenadores de Despesas & 90 & 111 & 87 & 69 & 98 \\
\hline Programas de Auditoria & 49 & 81 & 123 & 64 & 63 \\
\hline Relatório de Acompanhamento de Planejamento & 0 & 0 & 0 & 42 & 63 \\
\hline Tomada de Contas & 180 & 46 & 132 & 31 & 109 \\
\hline Tomada de Contas Almoxarifado & 0 & 3 & 2 & 1 & 0 \\
\hline Tomada de Contas Bens Patrimoniais & 129 & 256 & 194 & 181 & 83 \\
\hline Tomada de Contas Especial & 7 & 14 & 28 & 14 & 31 \\
\hline Transferência de Almoxarifado - Prestação de Contas & 4 & 5 & 6 & 12 & 3 \\
\hline Transferência de Bens Patrimoniais - Prestação de Contas & 80 & 169 & 197 & 181 & 112 \\
\hline Outros & 95 & 172 & 22 & 63 & 32 \\
\hline Total & 2509 & 3427 & 2847 & 2394 & 2313 \\
\hline
\end{tabular}

Fonte: AGE/RJ, 2014.

Os exames de prestação de contas desenvolvidos pela AGE/RJ são remetidos aos TCE/RJ para análise e julgamento dos ordenadores de despesas dos órgãos da administração pública estadual que utilizaram recursos. Os processos de tomadas de contas especiais, instaurados pelo TCE/RJ, são desenvolvidos para AGE/RJ para análise e apuração do dano gerado ao erário público para posterior cobrança ao agente causador. No quadro 2 nota-se um aumento significativo na quantidade de convênios analisados do ano de 2012 para 2013. Entretanto, identificou-se que o número de auditorias especiais nos últimos cinco anos foi de apenas duas, mesmo com a proximidade da realização de grandes eventos.

Como resultados da pesquisa, pretende-se nesse tópico, compreender a atuação da AGE/RJ no evento da Copa das Confederações de 2013 procurando explorar interfaces da accountability na administração pública no âmbito do poder executivo do Estado do Rio de Janeiro através da pesquisa documental e também de campo. Em função da magnitude do evento e das competências legais atribuídas à instituição em foco, o trabalho de campo resultou na discussão que se apresenta a seguir. 


\section{Leonardo da Silva Morais \& Maria Gracinda Carvalho Teixeira}

\subsection{A inserção da AGE/RJ na Copa das Confederações de 2013}

A Copa das Confederações é um evento organizado pela Federação Internacional de Futebol Associado (FIFA), e teve sua origem em 1992. Dados da FIFA (2013) registram que a partir de 2005, o torneio passou a ser realizado periodicamente sempre no ano anterior à Copa do Mundo. E tendo como participante, as seleções campeãs dos continentes, além da campeã da última edição da Copa do Mundo.

A Copa das Confederações está intrinsicamente ligada a Copa do Mundo, pois automaticamente, o país ao ser escolhido como sede do principal torneio mundial de seleções passa a ser também anfitrião da Copa das Confederações. Com isso, a Copa das Confederações passou a servir como evento teste para Copa do Mundo. Nesse sentido, o evento passou a ser uma preparação importante para o país anfitrião da Copa do Mundo da FIFA. Logo, é um momento para apresentar toda a infraestrutura pronta para receber o evento. Em função da proximidade entre os eventos, por consequência, grande parte dos recursos investidos para a realização da Copa do Mundo acaba sendo utilizada já na Copa das Confederações.

Por haver alocação de recursos públicos do Governo do Estado do Rio de Janeiro e em consonância com o Decreto 43.463/2012 (RIO DE JANEIRO, 2012), que definiu em seu artigo $2^{\circ}$, as finalidades do Sistema de Controle Interno, onde estão: (i) assegurar eficácia, eficiência e economicidade na administração e aplicação dos recursos públicos e (ii) gerar informações sobre a gestão pública, de modo a orientar a tomada de decisões. Assim sendo, fica subentendido por força de lei que essas finalidades pressupõem uma atuação da AGE/RJ de forma preventiva no controle dos gastos e subsidiando a administração quanto aos gastos públicos e nesse caso, para a realização da Copa das Confederações de 2013.

\subsection{Percepções dos sujeitos da pesquisa}

As entrevistas com os sujeitos da pesquisa permitiram confrontar as teorias apresentadas neste estudo e os dados levantados na pesquisa documental. O conteúdo dos relatos possibilitou extrair subcategorias, o que auxiliou na sistematização dos dados, como se observa no quadro 3.

REAd | Porto Alegre - Edição 83 - N 1 - Janeiro/Abril 2016 - p. 77-105 


\section{INTERFACES DA ACCOUNTABILITY NA ADMINISTRAÇÃO PÚBLICA BRASILEIRA: ANÁLISE DE UMA EXPERIÊNCIA DA AUDITORIA GERAL DO ESTADO DO RIO DE JANEIRO}

\begin{tabular}{|c|l|}
\multicolumn{2}{|c}{ Quadro 3 - Categorias e subcategorias } \\
\hline CATEGORIA & \multicolumn{1}{c|}{ SUBCATEGORIA } \\
\hline \multirow{2}{*}{ Accountability } & Prestação de contas, responsabilidade e ética \\
\cline { 2 - 2 } & Accountability na AGE/RJ \\
\hline \multirow{3}{*}{ Controle } & Preocupação com burocracia e formalismo \\
\cline { 2 - 2 } & Relacionamento institucional do órgão \\
\cline { 2 - 2 } & Dificuldades operacionais e políticas \\
\hline \multirow{3}{*}{ Responsividade } & Resposta à demanda de informação com responsabilidade pelos próprios atos \\
\cline { 2 - 3 } & Demandas por responsabilização \\
\cline { 2 - 2 } & Melhorias para responsividade \\
\hline \multirow{3}{*}{ Transparência } & Resposta à pressão para disponibilizar informação \\
\cline { 2 - 3 } & Limitada à divulgação das informações quando solicitadas \\
\cline { 2 - 2 } & Interação AGE/RJ e sociedade \\
\hline
\end{tabular}

Fonte: elaboração própria

Accountability - Dentre os diferentes entendimentos do conceito de accountability

foi possível identificar nos relatos, a sua associação principalmente à ética, prestação de contas a quem lhe delegou (incluindo aqui a sociedade) alguma responsabilidade, responsabilização e transparência.

"Primeiro, a prestação de contas para a sociedade, chamamos de controle social, expor o que está sendo feito e, num segundo momento, por toda normativa legal, prestar contas ao Tribunal de Contas do Estado a quem cabe julgar" (Entrevistado 03).

"Eu entendo que é prestar contas a alguém que te delegou alguma responsabilidade. Nós estamos numa esfera pública, portanto, devemos prestar contas à sociedade. A sociedade que tem que intermediar essas ações dos gestores públicos... E numa esfera maior o poder legislativo, então, isso é prestar contas a quem lhe delegou alguma responsabilidade. E com a responsabilidade, ética inserida nesse contexto" (Entrevistado 03).

“(...) accountability está relacionado ao contexto da transparência, a divulgação de informação por meio de internet e por meio de outdoor e por meio de quaisquer canais que possam estar efetivamente comunicando; quais foram às ações desses governantes, desses ordenadores de despesas em face do orçamento que eles precisavam executar, em face de abordagens financeiras operacionais e tantas outras" (Entrevistado 02).

Com o intuito de captar dos sujeitos as suas visões de accountability e como perceberam esse conceito na atuação da AGE/RJ na Copa das Confederações de 2013, verificou-se que a AGE/RJ não realizou um plano de trabalho voltado para a accountability limitando-se a auditoria à análise de aspectos financeiros e orçamentários:

\footnotetext{
“Até onde eu sei a AGE não elaborou um planejamento sistematizado para se auditar a Copa das Confederações; ela até pode ter feito isso de maneira isolada, por meio das coordenações de auditoria examinando contratos e convênios que possam ter sido executados, sobretudo contratos de obras que foram realizadas; até onde sei não elaborou, por exemplo, uma auditoria de natureza operacional com esse foco específico na Copa das Confederações" (Entrevistado 02).
}

"Nós não tivemos durante a Copa das Confederações, até onde os meus registros estejam atualizados, um programa prévio de acompanhamento da realização desse evento; a nossa participação da etapa do controle desse processo foi posterior - ele foi efetivamente financeiro e pontual, na medida em que ele foi 


\section{Leonardo da Silva Morais \& Maria Gracinda Carvalho Teixeira}

exercido em grande parte por uma secretaria dentro do governo, a Secretária do Esporte. Foram processos que serão avaliados, serão certificados financeiramente com respaldos e atestações produzidas por terceiros, então esses processos, depois de certificados, seguirão naturalmente para o julgamento do tribunal" (Entrevistado 01).

Percebeu-se o peso do conceito de accountability conforme chama atenção Campos (1990) o qual sugere ser o produto da relação entre os órgãos governamentais e os cidadãos. Assim também se observou a importância da noção de accountability de Raupp e Pinho (2014), assim como Pinho e Sacramento (2009) os quais enfatizam que a questão da prestação de contas explica apenas parte do conceito de accountability, cujo significado é muito mais abrangente, o que não se viu com clareza na noção de accountability na atuação da AGE/RJ.

Controle - As entrevistas acenam a preocupação com os formalismos, com que são tratados os processos e procedimentos na realização do controle interno. Apesar de alguns depoimentos atestarem que a organização está atenta ao controle externo e social, e que já existam normativas para tal, os sujeitos não revelam como, na prática, isto ocorre. Ao mesmo tempo, apontam para uma baixa demanda da sociedade sobre informações junto ao órgão.

\footnotetext{
"Existe obrigatoriedade de se certificar e relatar todos os processos que envolvam bens e direitos de cada responsável pela coisa pública no Estado do Rio de Janeiro, agora, com relação ao controle social, ainda não é muito difundido. Temos poucas demandas da sociedade. Recentemente até foi criada no Estado do Rio de Janeiro uma "Rede de Controle" da qual a Auditoria Geral faz parte, representando a Secretaria de Fazenda. É a única ação de controle social mais efetiva que temos nesse momento. Recentemente, nós realizamos a Conferência de Controle Social no Estado do Rio de Janeiro" (Entrevistado 03).
}
"As dificuldades nascem anteriormente ao Controle Interno, o Estado não é articulado. A gente percebe que o Estado não consegue demostrar para sociedade quem é o responsável por esses megaeventos... Quais os órgãos, o que vão fazer? Quais os resultados? Que tipo de orçamento? E aí compromete também o trabalho do Controle Interno, nem o cidadão sabe e muita das vezes no próprio Estado fica difícil a gente saber a quem procurar (...) no âmbito interno a dificuldade é a de recursos humanos" (Entrevistado 04).
“(...) na verdade o que a gente pode fazer é contribuir para verificar se os controles estão adequados e dar transparência à sociedade, com a chancela da Auditoria Geral do Estado" (Entrevistado 05).

Notou-se pelas entrevistas também que há dificuldades de atuação no tocante à transparência entre os órgãos do Estado, e entre esses órgãos e a sociedade, no que diz respeito ao controle. Registra-se uma desarticulação no âmbito estatal que pode estar interferindo na atuação da instituição em foco, no tocante aos controles e também parece haver carência de recursos humanos para dar cabo de uma atuação mais a priori, com maior foco no planejamento.

REAd | Porto Alegre - Edição 83 - № 1 - Janeiro/Abril 2016 - p. 77-105 


\title{
INTERFACES DA ACCOUNTABILITY NA ADMINISTRAÇÃO PÚBLICA BRASILEIRA: ANÁLISE DE UMA EXPERIÊNCIA DA AUDITORIA GERAL DO ESTADO DO RIO DE JANEIRO
}

Responsividade - Retomando a noção de responsividade de Mainwaring (2003, p.7), no sentido da "obrigação legal de responder a questionamentos e demandas de informações, com responsabilização pelos próprios atos”, na análise dessa categoria pretendeu-se evidenciar como os sujeitos da pesquisa lidam com a responsabilização de suas atividades na AGE/RJ. Nesse sentido orienta-se pelo entendimento de Mainwaring de que responsividade vai além da noção de responsabilidade. Notou-se um distanciamento da atuação do órgão com as manifestações das ruas e a cobrança da sociedade ao órgão:

\begin{abstract}
"Essas demandas da sociedade ainda não estão muito presentes no nosso trabalho, sobretudo, no Governo Estadual até onde eu tenho notícia... Não tenho acesso, a uma procura concreta de forma direta por parte da sociedade" (Entrevistado 02).

“(...) ainda não chegou à AGE; provavelmente isso poderá vir a acontecer muito mais pela obrigatoriedade de prestação de contas que um dia algum processo possa trazer; algum problema na área de responsabilização e que a AGE tenha que fazer uma tomada de contas até responsabilizar alguém, mas ainda não chegou por demanda da sociedade. (Entrevistado 04).

"Na verdade, a gente vem ao longo dos últimos anos... Nos últimos dois, três anos trabalhando isso, instituindo normas, instruções normativas que busquem o alcance maior nessa conduta pelo gestor. Minimizando possíveis erros ou equívocos por ações de controle" (Entrevistado 03).
\end{abstract}

Esse desencontro entre as demandas sociais e a prática de responsividade da AGE/RJ é observado também quando os sujeitos são abordados sobre quais os elementos mais importantes para serem avaliados para a emissão dos relatórios de auditorias, pois os entrevistados destacam gestão orçamentária, gestão financeira, patrimonial, gestão de suprimentos, gestão de licitações entre outros, porém a responsividade da execução orçamentária pareceu ser um elemento crítico.

\footnotetext{
"Recentemente nós fizemos uma escolha sobre a atuação a AGE pelo menos no relatório de prestação de contas, no exame de algumas gestões. Fizemos verificação, gestão orçamentária, gestão financeira, patrimonial, gestão de suprimentos, gestão de licitações, e por aí vai, então cada órgão é uma especificidade em relação a sua execução, a sua atuação, há órgãos que você vai fundamentalmente atribuir uma responsabilidade maior à questão financeira; outros que não recebem tantos recursos como contábeis, patrimoniais, serviços, então isso é muito próprio do órgão, da sua forma de atuação, da sua natureza...” (Entrevistado 01).

"Se a gente pensar que esses relatórios vêm de um trabalho concluído, de uma coisa que a gente está vendo a posteriori, muitas das vezes a gente tem que primeiro analisar se aquela prestação de contas atendeu às normas daquilo que era cobrado, daquilo que tinha que se contar de documentos... E se esses documentos dão embasamento para regularidades das ações, vendo se há o cumprimento da legalidade, se foi uso de recursos, se foi corretamente utilizado de acordo com as normas e orientações, sejam elas tributárias, previdenciárias ou de outra questão ou também de resultado..." (Entrevistado 04).

"Todos os relatórios da Auditoria Geral do Estado e atualmente os mais importantes são os que se referem à gestão de contas do governo do estado - se elas estão todas fundamentadas e lastreadas com os próprios relatórios oficiais do estado, então toda emissão de opinião está se baseando ou num relatório oficial do estado ou no sistema oficial do estado. Todo o nosso lastro de informação, de opinião está lastreado em documentos oficiais, então a garantia da credibilidade do conteúdo daquela informação está lastreado em documentos oficiais..." (Entrevistado 05).
} 


\title{
Leonardo da Silva Morais \& Maria Gracinda Carvalho Teixeira
}

Por ser um órgão vinculado à administração direta se observa com mais clareza, o atendimento aos formalismos legais mais conectados à responsabilização interna. Entretanto, percebe-se também uma preocupação com o controle da gestão de contas do governo do estado, o que pode estar sinalizando à sociedade uma tendência à responsividade.

Transparência - Como visto anteriormente na discussão teórica deste trabalho, answerability está articulada não apenas ao controle, mas também à transparência e deve estar relacionada à atitude, obrigatoriedade dos órgãos públicos. Não está referida apenas à resposta a uma pressão. Nesse sentido, as instituições devem estimular uma interação interna para que ocorra a responsividade dentro das próprias instituições, e também que devem estimular a answerability na aproximação com a sociedade.

Enquanto alguns entrevistados afirmaram que não houve efeito dentro da AGE/RJ das manifestações de rua, das demandas da sociedade em relação à Copa das Confederações de 2013 no sentido da cobrar transparência das informações sobre os recursos públicos relacionados ao evento esportivo em questão e ao destino desses recursos, outros afirmaram que foi discutido dentro da instituição as implicações das manifestações públicas no trabalho da AGE/RJ.

\footnotetext{
"Não houve nenhum impacto dessas manifestações. Prosseguiu-se com a mesma rotina da execução orçamentária das secretarias e órgãos envolvidos, caso lá tivesse alguma atividade. (...) ninguém questionou, mesmo com a Lei de Acesso a Informação. Eu nunca vi nenhuma ação da sociedade questionando, buscando maiores informações dentro do órgão central de controle interno do poder executivo do estado do Rio de Janeiro como desdobramento das manifestações" (Entrevistado 03).
}

\begin{abstract}
"Não me lembro de ter ocorrido pedidos de processo via LAI. Acho que a LAI ainda não pegou, não sei se é por desconhecimento ou se é por causa da burocracia... Acho que ela tinha que ser mais falada. De qualquer forma, não é um problema da AGE ou do governo do Estado. Nas reuniões da Rede de Controle a LAI é abordada e vejo que o problema acontece também nas outras esferas" (Entrevistado 04).

“A própria lei de acesso à informação... cujas leis equivalentes são adotadas em vários países, na grande maioria dos países eu acho que no contexto do Brasil, sobretudo no contexto dos governos estaduais, ela ainda é mal utilizada pela sociedade. Então, muitas das vezes as pessoas requerem informações via a LAI mais para obterem respostas à coisas relacionadas à documentação que elas mesmas precisam ou estudantes de pós-graduação que estão fazendo pesquisas, e aí solicitam determinadas informações sobre o governo. Mas eu acho que essa demanda da sociedade ainda não está muito presente, sobretudo, no Governo Estadual até onde eu tenho notícia" (Entrevistado 01).
\end{abstract}

Nota-se também, pelo relato abaixo que informações relacionadas à Copa das Confederações de 2013 estão incompletas e outras ainda não foram disponibilizadas ao público. Todavia, as informações disponíveis podem ser acessadas pelo portal e no próprio tribunal; podem ser verificadas as contas de determinada gestão.

"É um grande banco de dados disponível que pode ser consultado quando o cidadão pede vistas ao processo, ele pode ser consultado quando o cidadão acessa o 


\section{INTERFACES DA ACCOUNTABILITY NA ADMINISTRAÇÃO PÚBLICA BRASILEIRA: ANÁLISE DE UMA EXPERIÊNCIA DA AUDITORIA GERAL DO ESTADO DO RIO DE JANEIRO}

nosso portal, que está em desenvolvimento, eu não vou dizer que tem todas as
informações, ele está em desenvolvimento, esse trabalho que estamos fazendo
aqui, não estamos falando de um portal já consolidado, é um portal de
informação, mas já com uma quantidade considerável de informações, então eu
acho que a grande questão aí é a possibilidade de disponibilização desse
material, a parte interessada, a parte que estiver interessada ela tem esse
material disponível, o caminho pode ser o acesso ao portal, ele pode tomar vistas
ao processo, ele pode ter depois no próprio tribunal para que ele veja as contas de
determinada gestão, é um grande banco de dados disponível" (Entrevistado 01).

Embora a Lei de Acesso à Informação possibilite mais transparência e, por conseguinte, estimule maior exercício de direito à cidadania, fortalecendo a democracia, os estudiosos do tema transparência acenam para processos ainda complexo na inter-relação entre Estado e sociedade, quando o assunto é transparência, que se manifestam na maneira como os órgãos públicos entendem e se relacionam com os cidadãos e vice-versa, no tocante à transparência. Com bem lembra Campos (1990), enquanto nas democracias mais amadurecidas a textura política é caracterizada por uma bem-sedimentada rede de associações levando a accountability a fluir de forma mais espontânea nas suas instituições, nos países de democracia mais frágil, com a brasileira, além de não ocorrer dessa forma, julga-se ser um problema da sociedade se não há maior transparência nas ações dos governantes. Com efeito, a ausência ou fraca pressão social para a transparência é interpretada por vários gestores entrevistados como sendo um problema da sociedade, resultado de pouca educação política, de leis pouco utilizadas pela sociedade. Esse entendimento se choca com perspectivas mais atuais que acenam para o caráter proativo da transparência que deve ser incorporado pelos órgãos governamentais de modo que a informação seja disponibilizada de maneira completa e de fácil acesso e com linguagem adequada a um público mais amplo, ao invés de ficar limitada à divulgação das informações somente quando solicitadas.

\section{CONSIDERAÇÕES FINAIS}

Retomando o objetivo do trabalho, a pesquisa explorou o sentido do termo accountability e suas interfaces na administração pública brasileira apontando os avanços e entraves da accountability no Brasil a partir da análise da experiência da uma organização pública, a Auditoria Geral do Estado do Rio de Janeiro e sua atuação na Copa das Confederações de 2013. Assim acreditou-se que o estudo viria contribuir com evidências do Executivo brasileiro na questão da accountability, pois a base empírica do estudo possibilitaria tais evidências apesar de não se constituir um estudo de caso propriamente dito. 


\section{Leonardo da Silva Morais \& Maria Gracinda Carvalho Teixeira}

A pesquisa sinalizou que as competências da AGE/RJ no que concerne ao sistema de controles implicam na efetividade da accountability na aplicação dos recursos públicos e na geração de transparência. Entretanto, a instituição se depara com fortes limitações quanto a sua finalidade de controle na gestão dos recursos, o que compromete a accountability no tocante à responsividade. Entre as principais limitações, a pesquisa destaca o que aponta Abrucio (2004), que o sistema de controle interno brasileiro não está sendo ativado como um mecanismo de aperfeiçoamento da gestão pública estadual, pois há o predomínio do formalismo em detrimento de outras funções também relevantes. Suas relações com o controle externo, com o planejamento e com o controle social devem ser reforçadas para produzir mais informações e avaliações que permitam às administrações estaduais um maior aprendizado organizacional.

Em suas funções de controle, há um rito administrativo por meio de tramitação processual física, em que os órgãos da administração pública responsáveis pela aplicação dos recursos públicos ao final de um período, realizam abertura de um processo administrativo, com a elaboração das Prestações de Contas, que, em seguida tramitará para a AGE/RJ para a certificação da regularidade ou irregularidade dos recursos aplicados, e que por fim será remetido ao TCE/RJ para julgamento das contas.

Embora a realização das atividades formalísticas seja considerada vital à Auditoria, os dados revelam uma carência de aproximação entre a AGE/RJ e os demais órgãos da administração pública requerendo a realização de análises processuais voltadas não apenas para dentro da organização. Um exemplo da necessidade sentida dentro da própria organização para a abertura da AGE, junto a outros órgãos, se verifica em relatos quando é sugerido que a atuação de auditores nos órgãos para assessoramento evitaria problemas e danos ao erário público.

O foco principal do estudo foi identificar como a AGE/RJ gera informações no sentido de prover condições para transparência na gestão pública com base na experiência da Copa das Confederações de 2013. Foi registrado pelos entrevistados que a transparência foi possibilitada a posteriori, com a realização e disponibilização dos relatórios dos órgãos envolvidos no evento, chamando atenção para o fato de que esse é um processo normal na atuação da AGE/RJ.

No que pese o conhecimento dos gestores sobre o volume de recursos envolvidos e visibilidade para realização do evento, não houve planejamento por parte do órgão para que ocorresse o controle efetivo in loco, limitando-se à análise processual a posteriori pelas entidades envolvidas. A atuação in loco, conforme as teorias e também alguns

REAd | Porto Alegre - Edição 83 - N 1 - Janeiro/Abril 2016 - p. 77-105 


\section{INTERFACES DA ACCOUNTABILITY NA ADMINISTRAÇÃO PÚBLICA BRASILEIRA: ANÁLISE DE UMA EXPERIÊNCIA DA AUDITORIA GERAL DO ESTADO DO RIO DE JANEIRO}

relatos é fator determinante para que se efetive um controle com qualidade. Campos, nos anos de 1990, já chamava atenção à importância do "controle in loco", citando a atuação do Tribunal de Contas da União (TCU) em que inspeções in loco não eram feitas pelo TCU naquela época e baseava-se, sobretudo, em inquéritos formais sobre o conteúdo de relatórios contábeis e documentação de auditoria (CAMPOS, 1990).

Com base no aporte legal sobre o controle em órgãos públicos, sobretudo no Sistema de Controles na Administração Pública (SCAP), a pesquisa permite ressaltar que ações poderiam ter sido impetradas pela AGE/RJ no contexto da Copa das Confederações de 2013, visto que, dentre suas atribuições previstas pelo Decreto Estadual 43.463/2012 (RIO DE JANEIRO, 2012), está a de fiscalizar as atividades públicas, realizar Auditorias Especiais e sugerir ações voltadas para a aplicação dos recursos e até mesmo para o racionamento dos gastos públicos.

O aporte legal também ajuda a compreender que um megaevento como a Copa das Confederações de 2013 que possui compromissos e datas fixados, exige um controle interno do cronograma de execução para a sua realização; dessa maneira, o controle prévio torna-se relevante na garantia da execução orçamentária nos prazos previstos.

Mas, conforme visto na discussão sobre os três principais controles aos quais está sujeita a atuação da AGE/RJ, esse é apenas o primeiro passo para que se viabilize o controle social, uma vez que se as questões relativas ao controle interno não forem plenamente resolvidas dentro da organização, não haverá uma comunicação clara e transparente com o público solicitante das informações.

O estudo permitiu aos pesquisadores conhecer com mais profundidade o tema accountability e concluir que o assunto é complexo e que a sociedade fluminense pouco explora mecanismos de accountability junto a uma instituição como a AGE/RJ. A reflexão que a pesquisa possibilitou através da voz de seus depoentes, permite sugerir recomendações de continuidade do estudo, assim como de aperfeiçoamento dos controles na instituição pesquisada, a partir de: (i) disseminação do conhecimento e popularização da atuação da AGE/RJ através da abertura de diálogo com diferentes atores sociais (ONGs e outras organizações da sociedade civil, como sindicatos, escolas, universidades e outras instituições públicas e privadas); (ii) estabelecimento de parcerias com órgãos de ensino superior para discussão e debates sobre as formas e melhorias de processos de controle na atuação do órgão; (iii) edificação de mecanismos de transparência favorecendo o interesse do público pela atuação da AGE/RJ visto o contexto social onde opera a organização e seu importante 


\section{Leonardo da Silva Morais \& Maria Gracinda Carvalho Teixeira}

papel junto à sociedade brasileira, de contribuir para o fortalecimento da construção democrática do país a partir de um órgão público.

\section{REFERÊNCIAS}

ABRUCIO, F. L.; LOUREIRO, M. R. Finanças públicas, democracia e accountability: debate teórico e o caso brasileiro. In: ARVATE, Paulo R.; BIDERMAN, Ciro (Orgs.). Economia do setor público no Brasil. Rio de Janeiro: Elsevier/Campus, 2004, p. 75-102.

AUDITORIA GERAL DO ESTADO DO RIO DE JANEIRO - AGE. Portal institucional do órgão. Disponível em: <http://www.fazenda.rj.gov.br/sefaz/faces/sitios/sitios-auditorianavigation/folder/url?_adf.ctrl-state=12o9jfrn5s_50>. Acesso em 19 de out. 2014.

Relatório de Atividades. Disponível em: <http://www.fazenda.rj.gov.br/sefaz/ShowProperty?nodeId=\%2FUCMServer\%2FWCC226969\%2F\% 2FidcPrimaryFile\&revision=latestreleased $>$. Acesso em 10 de set. 2014.

BAQUERO, M. Democracia formal, cultura política informal e capital social no Brasil. Opinião Pública, v. 14, n. 2, p. 380-413, 2008.

BAUER, M. W. Análise de conteúdo clássica: uma revisão. Pesquisa qualitativa com texto, imagem e som: um manual prático, v. 4, p. 189-217, 2005.

BOBBIO, N; NOGUEIRA, M. A. O futuro da democracia: uma defesa das regras do jogo. Rio de Janeiro: Paz e Terra, 1986.

BRASIL. Constituição da República Federativa do Brasil 1988. Casa Civil. Brasília, DF:Senado, 05 out. 1988. Disponível em: < http://www.planalto.gov.br/ccivil_03/constituicao/constituicao.htm>. Acesso em: 17 abr. 2013.

Lei no 12.527, de 18 de novembro de 2011. Lei de Acesso à Informação. Regula o acesso a informações previsto no inciso XXXIII do art. 5o, no inciso II do § 3o do art. 37 e no § 20 do art. 216 da Constituição Federal; altera a Lei no 8.112, de 11 de dezembro de 1990; revoga a Lei no 11.111, de 5 de maio de 2005, e dispositivos da Lei no 8.159, de 8 de janeiro de 1991 e dá outras providências. Brasília: Presidência da República. Casa Civil. Subchefia para Assuntos Jurídicos. Disponível em: <http://www.planalto.gov.br/ccivil 03/ ato2011-2014/2011/lei/112527.htm>. Acesso em: $17 \mathrm{abr}$. 2013.

CAMPOS, A. M. Accountability: quando poderemos traduzi-la para o português? Revista de Administração Pública, FGV, Rio de Janeiro, v. 24, n. 2, mar./abr. p. 30-50, 1990.

CENTRO LATINO AMERICANO DE ADMINISTRAÇÃO PARA O DESENVOLVIMENTO CLAD. La responsabilizacion en la nueva gestion pública latinoamericana. Buenos Aires: CLAD/ BID, 2000. Disponível em: <www.clad.org/siare_isis/innotend/control/control-nc.pdf >. Acesso em: 20 ago. 2013.

REAd | Porto Alegre - Edição 83 - № 1 - Janeiro/Abril 2016 - p. 77-105 


\section{INTERFACES DA ACCOUNTABILITY NA ADMINISTRAÇÃO PÚBLICA BRASILEIRA: ANÁLISE DE UMA EXPERIÊNCIA DA AUDITORIA GERAL DO ESTADO DO RIO DE JANEIRO}

DAHL, R. A.; LIMONGI, F.; PACIORNIK, C. Poliarquia: participação e oposição. São Paulo: Edusp, 1997.

DENZIN, N. K.; LINCOLN, Y. S. O planejamento da pesquisa qualitativa: teorias e abordagens. Porto Alegre: Art, 2006.

HEALD, D. Varieties of Transparency. In: HOOD, C.; HEALD, D. (Org.) Transparency. The key to better governance? New York: The British Academy, 2007, p. 25 - 44.

LIMA, L. H. Controle externo: teoria, legislação, jurisprudência e mais de 450 questões. Rio de Janeiro: Elsevier, 2008.

MAINWARING, S. Introduction: Democratic accountability in Latin America. In: MAINWARING, S.; WELNA, C. (Orgs.) Democratic accountability in Latin America. Oxford: Oxford University Press, 2003, p.3-33.

MEDEIROS, A. K.; CRANTSCHANINOV, T. I.; SILVA, F. C.. Estudos sobre accountability no Brasil: meta-análise de periódicos brasileiros das áreas de administração, administração pública, ciência política e ciências sociais. Revista de Administração Pública. FGV, Rio de Janeiro, vol. 47, no3, p. 745-775, mai/jun. 2013.

MICHENER, G.; BERSCH, K. Conceptualizing the Quality of Transparency. The 1st Global Conference on Transparency. Newark: Rutgers University, 19 - 20 mai. 2011, p. 1-28.

MONTESQUIEU, C. L. Do espírito das leis. In: Coleção 'Os Pensadores'. São Paulo: Abril Cultural, 1985.

NAKAGAWA, M.. Introdução à controladoria: conceitos, sistemas, implementação. São Paulo: Atlas, 1998.

O’DONNELL, G. Accountability horizontal e novas poliarquias. Lua Nova, São Paulo, n. 44, p.2754, 1998.

PESSANHA, C. Accountability e Controle Externo no Brasil e Argentina. In: Direitos e Cidadania Justiça, Poder e Mídia, CASTRO, A. G. (Coord.), Rio de Janeiro: FGV, 2007, p. 139-167.

Controle externo: a função esquecida do Legislativo no Brasil. In:

SCHWARTZMAN et al. (Orgs.) O sociólogo e as políticas públicas. Rio de Janeiro: FGV, 2009, p.243-258.

PINHO, J. A. G.; SACRAMENTO, A. R. S. Accountability: já podemos traduzi-la para o português? Revista de Administração Pública, FGV, Rio de Janeiro, v. 43, n. 6, p. 1343-1368, nov./dez. 2009.

PLATT NETO, O. A.; CRUZ, F.; ENSSLIN, S. R.; ENSSLIN, L. Publicidade e Transparência das Contas Públicas: obrigatoriedade e abrangência desses princípios na administração pública brasileira. Contabilidade Vista \& Revista, v. 18, n. 1, p. 75-94, jan./ mar. 2007.

REAd | Porto Alegre - Edição 83 - № 1 - Janeiro/Abril 2016 - p. 77-105 


\section{Leonardo da Silva Morais \& Maria Gracinda Carvalho Teixeira}

POWER, M. The audit society - rituals of verification. Oxford: Oxford University Press, 1999.

RAUPP, Fabiano Maury; PINHO, José Antonio Gomes de. Prestação de contas nos portais eletrônicos de Assembleias Legislativas: um estudo após a Lei de Acesso à informação. Revista Gestão e Planejamento, v. 15, n. 1, p. 144-161, jan./abr. 2014.

RICHARDSON, R. et al. Pesquisa social: métodos e técnicas. 3a . ed. São Paulo: Atlas, 1999.

RIO DE JANEIRO. Decreto Estadual no 43.463 de 14 de Fevereiro de 2012. Dispõe sobre o Sistema de Controle Interno do Poder Executivo Estadual. Disponível em: $<$ http://www.fazenda.rj.gov.br/sefaz/content/conn/UCMServer/path/Contribution\%20Folders/ site fazenda/legislacao/financeira/decretos/2012/43.463.html>. Acesso em 19 de out. 2013.

SACRAMENTO, A. R. S.; PINHO, J. A. G. Corrupção e Accountability no Brasil: Um Olhar A Partir de Organizações da Sociedade Civil. In: ENCONTRO DE ADMINISTRAÇÃO PÚBLICA E GOVERNANÇA DA ANPAD, 2012, Rio de Janeiro, Anais... Rio de Janeiro: Anpad, 2012.

SANO, H. Nova Gestão Pública e accountability: o caso das organizações sociais paulistas. 2003. Dissertação (Mestrado em Administração Pública) - Escola de Administração de Empresas de São Paulo, Fundação Getúlio Vargas, São Paulo. 2003.

SECRETÁRIA DE FAZENDA DO ESTADO DO RIO DE JANEIRO. Portal de acesso a SEFAZ/RJ. Disponível em: < http://www.fazenda.rj.gov.br/portal/>. Acesso em 10 jan. 2014.

SERRA, R. C. C. CARNEIRO, R. As Interfaces Entre o Controle Social e os Controles Externo e Interno na Administração Pública Brasileira. In: ENCONTRO NACIONAL DA ANPAD, 2011, Rio de Janeiro. Anais... Rio de Janeiro: Anpad, 2011.

TRANSPARENCY INTERNATIONAL. The Anti-Corruption Plain Language Guide. Disponível em www.transparency.org Acesso em 10 mar. 2014. 